\title{
The Role of ECOWAS on Economic Governance, Peace and Security Perspectives in West Africa
}

\author{
Isaac Terungwa Terwase
}

Ghazali Shafie Graduate School of Government, College of Law, Government and International Studies (COLGIS), Universiti Utara Malaysia, 06010 Sintok, Kedah, Malaysia isaacterwase1@gmail.com

\section{Asmat-Nizam Abdul-Talib}

\begin{abstract}
School of International Studies, College of Law, Government and International Studies,
\end{abstract} Universiti Utara Malaysia, 06010 Sintok, Kedah, Malaysia

\author{
Knocks Tapiwa Zengeni \\ School of International Studies, College of Law, Government and International Studies, \\ Universiti Utara Malaysia, 06010 Sintok, Kedah, Malaysia
}

Doi:10.5901/mjss.2015.v6n3p257

\begin{abstract}
The West African States are known as States with endowed natural and human resources that ought to have an enlargement in the area of economic growth and development. This will help yield results to the countries in West Africa through economic cooperation among states within the region. It is therefore, the goal and objective of the Economic Community of West African States (ECOWAS) to promote regional integration and co-operation for the purpose of ensuring economic growth and development in the sub-region. The endowed resources in West African states are mostly untapped due to challenges that face the region such as lack of technological know-how, bad governance, political instability, lack of adequate diversification, infrastructure problem, lack of political will and the inability to involve the private sector adequately. Therefore, the objectives of this study is to firstly, create an enabling environment where peace and security is sustainable for West African states to engineer economic governance through regional integration and economic co-operation among the countries in West Africa, and secondly, to enable partnership with the private sector. The methodology used in this research is review of previous literature and the use of content analysis which will also provide useful information on the region. The findings from this study reviews that, peace and security sustainability can only be maintained when the West African States employ the measures that would lead to economic growth and development of the region through provision of job opportunities to the youths, employing the early-warning mechanism, transparency and accountability in governance and good leadership to foster growth of ECOWAS community.
\end{abstract}

Keywords: ECOWAS, Economic governance, Peace and Security perspective, Partnership.

\section{Introduction}

The West African sub-region is endowed with human, agricultural and natural resources which the states in the said region sought to cooperate and to promote economic integration. The Economic Community of West African States (ECOWAS) was established for this reason in 1975 for the purpose of engineering economic growth and development of the region given her endowed resources. Among others, the region contributes to the growth of the African economy as well as the global economy through her resources which are exported from the region to other parts of the world.

It is therefore, a region that needs to be studied in resolving some of the conflicting issues that surround the West African States, so as to provide suitable solutions to such issues as we look at the bases of setting up the sub-regional organization known as ECOWAS. This will take us to understanding the role of ECOWAS in ensuring and enhancing good economic governance, and the role of sustaining peace and security in the region so that the main purpose of its establishment would be achieved. This study has also focused on revealing some of the issues that could affect the region when the said economic governance is not taken into consideration in relation to transparency, accountability, financial management, fight against corruption, fight against poverty, unemployment, health related issues, and 
importantly, to relate such with security issues.

Terwase, Abdul-Talib and Zengeni (2014), relate their work to the endowed resources in Nigeria that are still untapped while many people are in search of job opportunities in the case of Nigeria. In the said country which is the most populated state in West Africa and the host of ECOWAS Headquarters in Abuja, the country is richly blessed with both human and natural resources; however, her overdependence on oil has left other resources untapped while her people in the rural communities live within endowed resources but die of poverty. This work has looked into such issues as it affects the security of the people when government neglects functional economic governance.

For the European Union (EU) as a regional body, it looks at the preventive measures that can seek to foster economic growth and stability, while tackling issues that could make or result into economic problems. As such, it has agreed to ensure policies that would lead to economic growth and development of the region (European Union, 2014). When these issues are not taken care of, it may then have some negative effects on the political life of the state which may also lead to insecurity of the said environment and region as the case may be. This paper has reviewed the relevance of economic governance as well as security issues as it relates to poor governance as well as the role of ECOWAS in ensuring regional economic governance, the security of the people and region through transparency, accountability, early warning mechanism, conflict prevention, conflict resolution and post-conflict reconstruction in West Africa.

The objective of this study therefore, is to bring to the fore some of the major issues that can bedevil the development of the ECOWAS community and to take measures that would lead to the growth of the region, promote the development of the West African States as well as employ the missing link. Like other countries in Europe, Asia, and America, they target at economic growth and development of their countries in order to enhance the overall wellbeing of their citizenry. As such, this paper focuses on the issues that need to be addressed in the West African region in order to promote peace and security of the sub-region, promote both economic integration and cooperation of the said states so as to bridge the gaps therein through good governance and good leadership in West African States.

\section{Literature Review}

Deas, Hincks and Headlam (2013) argued that, changes can affect a regional geographical establishment which also relates to local, national as well as international economic development. This becomes very important to this study as countries within the West African sub-region established ECOWAS as a body with the aim of promoting economic development and international integration. But after many years of its establishment, there are still many challenges facing the West African countries. Thus, the issue of economic governance becomes relevant to this study as well as the security implications therein. Benit-Gbaffou, Didier and Morange (2008) reveals how private-public partnership can be used as a tool in economic and security governance as they studied city improvement scheme in Cape Town and Johannesburg, South Africa. Therefore, they sought to balance access to equal security opportunities and treatment of the people.

In the view to seeking out issues affecting economic governance, Verdun (2013) relates it to the role of the European Union as a regional organization in Europe that reveals how democratic accountability can affect economic governance when it is lacking within the countries therein. This also reveals a major issue that is affecting not only the ECOWAS community but other regional bodies and countries even in Africa especially the sub-region under study. Adams and Mengistu (2008) in their work, focused on how privatization can be implemented yet it does not have significant impact on economic growth as well as income inequality, but the major substance is good governance.

Economic problems such as highlighted previously, can then be prevented through the process of ensuring stability and growth of economic policies that would gear towards the advancement of such countries involved. It can also be done through sound public finances which can thus, boost job opportunities leading to economic development and national growth (European Union, 2014).

What then is the linkage between economic governance, peace and security? Lindberg (2001) argued that, trade can be seen as a main function of states which can be conducted by the private sector in negotiation with the state; it is then expected of the state to provide the needed strategies that would enhance economic governance towards services that can be provided to the people as well as public governance leading to the security of the people. Issues such as unemployment, poverty, illiteracy, as well as poor governance are the main challenges that may lead to youth's engagement in activities such as militancy and insurgency against the government of a given state like in the case of Nigeria, Mali, Niger, and Liberia (Dike, 2014; Olaiaya, 2014; Yusuf, 2013; Aghedo, 2012; Salaam, 2012; Jackson, 2007).

In the case of Nigeria, Dike (2014) and Olaiaya (2014) observed that, the youths who are involved in the activities of the Boko Haram militancy against the Nigerian government do so as a result of unemployment, some as a result of 
illiteracy and driven by poverty, they find themselves engaging in the Boko Haram activities such as bombing of private and public facilities and killing of innocent lives. Thus, it is the responsibility of the West African states to focus on good governance in order to improve on the social conditions of their people and citizenry. Johnson (2007) argued that, ECOWAS countries suffer setbacks in relation to economic growth and development due to poor governance, weak institutions as well as issues relating to security challenges which are factored in unemployment, corruption, poverty, and failure on the part of the government to provide basic services to the people.

\section{The Challenges of Economic Governance, Peace and Security in West Africa}

What do the people expect from their leaders? How can such expectations be accomplished? Here we are looking at the issues that affect economic governance leading to unanswered questions that the people expect from states within the sub-region to be answered. Since the establishment of ECOWAS in 1975 as a regional organization in the West African sub-region, the expectations of the people goes beyond having a government in place in their respective countries, but seeing results for the purpose of its establishment. Within the sub-region, there are countries that went through civil war, had conflicts within states, and had military regimes as well as democratic governance. There are challenges that arose from lack of transparency and accountability, mismanagement of public funds, poverty, as well as unemployment of the citizenry. The role of states here covers not only signing of treaties but ensuring good economic governance where the people are well taken care of in relation to proper management of resources in order to promote national economic growth and development.

As such, the stability and growth of the economic policies that would ensure both the development of the people through provision of services such as jobs for the people, infrastructure, and accountability on the part of the government towards her role in developing the state, is what the people expect from their leadership. Furthermore, failure on the part of the government to meet the expectations of its citizens creates an environment for insecurity. This shall be discussed in order to relate to how it affects the West African states, and the role of ECOWAS therein on how to prevent such occurrences.

\subsection{Unemployment}

Unemployment of the youths as a result of bad governance had its untold effects on the wellbeing of countries that went through war. These unemployed youths were used during the war and these were periods of political conflicts due to the availability of the youths who were basically unemployed and were taken advantage of. They become available to be used at any given time since the value for their lives was no longer placed. This is one way of ensuring sustainable development through provision of job opportunities to the youths within the countries under the ECOWAS body (ECOWAS Commission, 2014). As in the case of the insurgency in Nigeria, most of the people who are directly involved are the youths who found themselves virtually uneducated as well as unemployed either by way of acquiring skilled or unskilled jobs.

\subsection{Poverty}

The communities and villages in the West African states especially in the sub-region are basically endowed with resources but the people living in such environments continue to suffer untold hardship as a result of their poverty driven environments. This kind of environment tends to be useful in the hands of actors to fight the government during conflict periods. To some, they leave on less than one dollar a day where they expect the government to intervene in their situations and provide economic policies that would lead to the development of such communities. However, when solutions to such issues are not sought after, the people living therein become tools in the hands of warlords and conflicts mount against the government.

\subsection{Transparency and Accountability}

This is one of the most important areas of focus which some countries tend to neglect. In any government, the leadership in place is being watched by the people irrespective of whether it is a democratic, military regime, monarch or even authoritarian government that are in leadership. In most cases, the people may tend to ignore for a while, but a time comes when they fight back against a seating government when the leadership in place is not accountable to the people on how the resources are being managed, and evidence of corrupt government may tend to face security challenges. 
Good governance therefore, would ensure transparency and accountability in management of the available resources where economic policies that would lead to the development of such country can be enhanced.

\section{The Role of Ecowas in Sustaining Economic, Peace and Security Governance}

There are mechanisms that can be put in place to monitor the development of West African States, be it economic cooperation between states, economic integration, peace and security sustainability, the fight against corruption, control of small arms and cross-border crime by ECOWAS. These are some of the issues that would be discussed in order to understand ECOWAS' role in ensuring economic, peace and security governance within the sub-region.

\subsection{The Early-warning Mechanism:}

Through the provision of an early-warning system by the ECOWAS Commission, it will enable the development of a monitoring system where issues that may affect any of the member states, will then be looked into before it would lead to any form of conflict (ECOWAS Commission, 2014). Conflict prevention mechanism in this case should be applied so as to enhance a resolution of issues that if not resolved may escalate into war. It could even be economic or political issues due to bad governance. As a result, jobs should be provided to the youths, provision of educational facilities through establishment private-public partnership to focus on eradicating all forms of illiteracy in the West African sub-region, creating an enabling environment for foreign direct investment to boost the utilization of the untapped resources in the sub-region so as to eradicate poverty, enhance both job creation and economic development of the states in order to solve the problems that are related to unemployment and security challenges.

\subsection{Economic Cooperation and Integration:}

The most significant issue that brought the idea of establishing ECOWAS was based on member states to cooperate among themselves for the purpose of promoting economic cooperation and integration. However, after many years the sub-regional establishment is still facing challenges in relation to such development and sustainability to which it was established. ECOWAS' role therefore, can be focused on resolving such challenges through ensuring transparency and accountability in governance from the political point of view to economic face amongst the member states. This will go a long way in fostering growth and development in the region. Hence, issues such as corruption should be highly fought by encouraging and campaigning for zero tolerance on corrupt practices in dealing with public issues, thereby putting the interest of the state first rather than personal interest. This would promote good governance within the sub-region and when the interest of the masses comes first, national interest is then placed and it then discourages personal interest.

\section{Conclusion}

In conclusion, the endowed resources in the West African sub-region can be developed through the cooperation and integration of the states involved. The issues that can lead to the underdevelopment of the region are traced to bad governance, corrupt practices by the leadership in government, negligence of the masses needs, placing of personal interest first above national interest especially those in leadership at any level, these are the problems that are truly facing the states. These issues need to be resolved for the countries within the sub-region to move forward. Therefore, ECOWAS should apply the early-warning mechanism in relating with the states or else face the consequences therein when the people are neglected. This negligence will then provide an avenue for insecurity of both the states and the subregion. Examples of countries that have witnessed such crisis in the region are Liberia, Cote d'Ivore, Mali, and Nigeria.

It is therefore the role of ECOWAS to see to it that early-warnings are passed to the states when there are effective monitoring systems within the regional body. This will encourage good governance, zero tolerance to corrupt practices, ensure transparency and accountability in governance be it political, economic and socio-cultural dimensions in order to eradicate all forms of challenges facing the sub-region such as poverty, illiteracy, unemployment, economic backwardness, and poor leadership at all levels. This would lead to the transformation of the sub-region through promotion of economic growth and development where private-public partnership could be encouraged and engaged, as well as partnership among other countries within and outside Africa for the purpose of engineering production and enhancement of the available resources therein. 


\section{References}

Adams, S. and Mengistu, B. (2008) Privatization, Governance and Economic Development in Developing Countries, Journal of Developing Societies, 24, (4): 415-438, DOI: 10.1177/0169796X0902400401

Aghedo, I. (2012) Winning the War, Losing the Peace: Amnesty and the Challenges of Post- Conflict Peace-Building in the Niger Delta, Nigeria, Journal of Asian and African Studies, 48(3), 267-280, DOI: 10.1177/0021909612453987

Benit-Gbaffou, C., Didier, S. and Morange, M. (2008) Communities, the Private Sector, and the State: Contested Forms of Security Governance in Cape Town and Johannesburg, Urban Affairs Review, Volume 43 Number 5, 691-717, DOI: 10.1177/10780 87407309223

Deas, I., Hincks, S. and Headlam, N. (2013) Explicitly Permissive? Understanding actor Interrelationships in the Governance of Economic Development: The Experience of England's Local Enterprise Partnerships, Local Economy, 28(7-8) 718-737, DOI: 10. $1177 / 0269094213500625$

ECOWAS Commission, (2014) Early Warning/Observation Monitoring Centre, Retrieved from http://www.comm.ecowas.int dept/stand. php?id=h_h2_brief\&lang=en

ECOWAS Commission, (2014) Gender, Youth, CSO, Employment, Drug Control Directorate, Retrieved from http://www.comm.ecowas. int/dept/stand.php?id=e_e2_brief\&lang=en

European Union, (2014) EU Economic Governance, Retrieved from http://ec.europa.eu/economy_finance/economic_governance lindex_en.htm

Jackson, A. (2007) Nigeria: A Security Overview, The Round Table: The Commonwealth Journal of International Affairs 96: 392, 587603, DOI: 10.1080/00358530701626040

Lindberg, S. (2001) Forms of States, Governance, Regimes: Reconceptualizing the Prospects for Democratic Consolidation in Africa, International Political Science Review, Vol. 22, No 2, 173-199

Olaiaya, T. A. (2014) Youth and Ethnic Movements and Their Impacts on Party Politics in ECOWAS Member States, Sage Open, January-March, 1-12, DOI: 10.1177/2158244014522072

Salaam, A. O. (2012) Boko Haram: beyond religious fanaticism, Journal of Policing, Intelligence and Counter Terrorism, 7:2, 147-162, DOI: $10.1080 / 18335330.2012 .719096$

Terwase, I. T., Abdul-Talib, A. N. and Zengeni, K. T. (2014) Nigeria, Africa's Largest Economy: International Business Perspective, International Journal of Management Sciences, Volume 3, Issue 7, pages: 534-543

Verdun, A. (2013) The Building of Economic Governance in the European Union, European Trade Union Institutes, 19(1) 23-35, DOI: $10.1177 / 1024258912469343$

Yusuf, H. O. (2013) Harvest of violence: the neglect of basic rights and the Boko Haram insurgency in Nigeria, Critical Studies on Terrorism, 6:3, 371-391, DOI: 10.1080/17539153.2013.835528 